\title{
Simultaneous production of lignocellulolytic enzymes and extraction of antioxidant compounds by solid-state fermentation of agro-industrial wastes
}

\author{
Paulina Leite, Cátia Silva, José Manuel Salgado*, Isabel Belo \\ Centre of Biological Engineering, University of Minho, Campus de Gualtar, 4710-057, Braga, Portugal
}

\section{A R T I C L E I N F O}

\section{Keywords:}

Solid-state fermentation

$\beta$-Glucosidase

Antioxidant compounds

Agro-food wastes

\begin{abstract}
A B S T R A C T
In recent years, the interest to find alternative extraction methods has increased. Extraction of natural phenolics by enzymes produced during solid-state fermentation (SSF) is a useful and novel technique environmentally friendly. On the other hand, agro-industrial wastes are an excellent source of natural antioxidants as phenolics.

The aim of the work was to evaluate the increase of antioxidant compounds extraction from agro-industrial wastes after SSF and to relate it to the production of lignocellulolytic enzymes. Several filamentous fungi were evaluated as candidates to increase the extraction of antioxidant compounds by solid-state fermentation of wineries, olive mill and brewery wastes. Fermented and unfermented agro-industrial wastes were extracted with water and lignocellulolytic enzymes, total phenolic compounds and antioxidant activity were determined in the extract. The maximum xylanase and cellulase activities were achieved by $A$. ibericus strains using brewer's spent grain (BSG) as substrate and ranged from 300 to $313 \mathrm{U}$ xylanase/g and 51-62 U cellulase/g. The best producer of $\beta$-glucosidase was $A$. niger CECT2088 using BSG as substrate (94 $\pm 4 \mathrm{U} / \mathrm{g}$ ). The results of extraction of phenolic compounds revealed a higher extraction by SSF in olive mill wastes followed by winery wastes. In the same form, the maximum increase of antioxidant activity was achieved by SSF of exhausted olive pomace by Rhizopus oryzae MUM 10.260, increasing 12.9-fold in relation to unfermented waste. In addition, the production of enzymes, the extraction of phenolic compounds and the increase of antioxidant activity were related by principal component analysis. The first component grouped the BSG along with maximum enzymes production, the second component related positively the production of enzymes and the extraction of phenolic compounds and the increase of antioxidant activity.

SSF proved to be an innovative environmentally friendly process that can improve the extraction of antioxidant compounds and simultaneously to produce lignocellulolytic enzymes from different agro-industrial wastes.
\end{abstract}

\section{Introduction}

Global Food production must increase by $60 \%$ by 2050 due to the growth of world population (FAO). This increment will cause a higher production of agro-food wastes. On the other hand, the European commission has an ambitious strategy of circular economy implementation. In this strategy, turning agro-food wastes into a resource is a priority for closing the loop, avoiding the agro-food wastes to be burned or landfilled.

Olive oil and winery wastes are excellent sources of natural antioxidants as phenolic compounds. More than 30 biophenols and related compounds have been identified in olive mill wastes (Obied et al., 2005). Hydroxytyrosol is one of the major phenolic compounds in olive fruit which has pharmacological and antioxidant activity (Bendini et al., 2007). Grape pomace also has several phenolic compounds as phenolic acids (gallic, syringic and caffeic acids) flavonoids (catechin, epicatechin), monomers and superior phenolics with antioxidant activity, anti-inflammatory properties, anti-proliferation and cancer therapy effects (Tournour et al., 2015). Brewery wastes were also reported as valuable source of phenolic compounds (Meneses et al., 2013). The most significant phenolic acids in BSG are ferulic and pcoumaric acids (Bartolomé et al., 2003, 1997). Like this, brewery waste becomes important to be valorized and used in other industries, such as, health, food, pharmaceutical and cosmetic. The ferulic acid has antioxidant properties, is an antimicrobial and anti-inflammatory agent, works as photoprotectant, and p-coumaric, has antioxidant properties, and it can be used as chemoprotectant (Bartolomé et al., 2002; Faulds et al., 2002; Mussatto et al., 2007).

\footnotetext{
* Corresponding author.

E-mail address: jmsalgado@ceb.uminho.pt (J.M. Salgado).
} 
These compounds can be extracted by conventional solvent extraction (Rodríguez-Solana et al., 2014). However, the total recovery of them can be difficult because those compounds are present as insoluble bound form conjugates with sugars, fatty acids or amino acids (Dey and Kuhad, 2014). In addition, the public awareness of health, environment and safety hazards associated with the use of organic solvents in processes and the possible solvent contamination of the final products together with the high cost of organic solvents, led to the development of a new and clean technology (Lafka et al., 2011). Extraction of natural phenolics by enzymes produced by solid-state fermentation (SSF) is a useful technique. Different carbohydrolases produced by the microorganisms can release the bound phenolics into soluble form (Bhanja et al., 2009). $\beta$-glucosidase are carbohydrate-hydrolysing enzymes that have important influence on the mobilization of soluble phenolics (Bei et al., 2018). In addition, cellulases and xylanases can break the cell wall of vegetal biomass and releases the insoluble phenolics (Bei et al., 2018).

The application of SSF to produce these enzymes is a suitable process, since it uses low cost conditions through of cheaper substrate such as agro-industrial wastes (Pandey, 2003). This bioprocess is environmentally friendly because produces less wastewater and has low energy requirements. It simulates the natural habitat of fungi what makes the preferred choice for these microorganisms to grow and produce useful value-added products (Singhania et al., 2009).

This study evaluated the production of $\beta$-glucosidase, cellulase and xylanases by solid-state fermentation (SSF) of olive mill, winery and brewery wastes using several filamentous fungi, the extraction of phenolic compounds from fermented wastes and the effect of SSF on antioxidant activity. In addition, the effect of enzymes produced were related with the extraction of phenolic compounds and antioxidant activity by principal component analysis.

\section{Materials and methods}

\subsection{Raw material and reagents}

Exhausted mixed white and red grape marc (EGM), vine shoots trimming (VTS) and grape stalks (GS) from the winery industry; organic crude olive pomace ( $\mathrm{COP}^{\text {org }}$ ), crude olive pomace (COP) and exhausted olive pomace (EOP) were collected from olive oil industry, and brewer's spent grain (BSG) from the beer industry during the season 2016/2017 from north of Portugal. These residues were dried at $65^{\circ} \mathrm{C}$ in a stove during $24 \mathrm{~h}$ and stored at room temperature.

The reagents used in principal experiments this study were 2,2-diphenyl-1-picrylhydrazyl (Sigma-Aldrich), methanol (Fisher Chemical) and trolox (Sigma-Aldrich) for antioxidant capacity. For $\beta$-glucosidase activity used nitrophenyl b-D-glucopyranoside (Sigma-Aldrich), p-nitrophenol (Sigma-Aldrich) and sodium carbonate (Fluka). In xylanase activity were used xylan (Sigma-Aldrich), citric acid monohydrate (VWR), sodium citrate dihydrate (Inlab), sodium carbonate (Fluka), 3,5-dinitrosalicylic acid (Acros Organics) and xylose (Sigma-Aldrich). For cellulase activity the same reagents were used, but xylan was replaced by carboxymethylcellulose (Sigma-Aldrich) and xylose by glucose (Fisher Chemical). In Folin-Ciocalteau method were used FolinCiocalteau reagent (AppliChem Panreac ITW Companies), sodium carbonate (Fluka), caffeic acid (Fluka), ethanol (Fisher Chemical). In solid state fermentation was used urea (VWR Chemicals ProLab), and for sterile solution for inoculation peptone (Chem Lab NV) and tween-80 (Fisher Cientific).

\subsection{Characterization of solid substrate}

Wastes were analysed in terms of physical and chemical characteristics (Table 1). Moisture and total solid contents were determined by drying in an oven at $105^{\circ} \mathrm{C}$ during $24 \mathrm{~h}$ to a constant weight. Ashes were determined by high temperature treatment at $575^{\circ} \mathrm{C}$ during $2 \mathrm{~h}$ in a muffle. Determination of cellulose, hemicellulose and lignin by quantitative acid hydrolysis were carried out following the methods described by Leite et al. (2016). N content was analysed by Kjeldahl method. Reduction sugars, total phenols and free protein were analysed in the liquid obtained after extraction process with water (ratio solid:liquid, 1:5 w/v). Reducing sugars were analysed by 3,5-dinitrosalicylic acid (DNS) method, soluble proteins were determined by Bradford method and total phenols were determined by the Folin-Ciocalteau method.

\subsection{Microorganisms}

Five fungi with potential for $\beta$-glucosidase production were selected in a previously stage. Aspergillus ibericus MUM 03.49, Aspergillus ibericus MUM 04.86 and Rhizopus oryzae MUM 10.260 were obtained from MUM (Micoteca of University of Minho, Braga, Portugal); Aspergillus niger CECT 2915 and Aspergillus niger CECT 2088 from CECT (Valencia, Spain) culture collection. They were revived on potato dextrose agar (PDA) plates. To obtain inoculum for SSF, the selected fungi were cultured on PDA slants, and incubated at $25^{\circ} \mathrm{C}$ for 6 days.

\subsection{Solid-state fermentation}

SSF process was carried out in glass petri dishes with $2 \mathrm{~g}$ of dry substrate. Moisture level was adjusted to $75 \%$ (wet basis) with distilled water and the ratio $\mathrm{C} / \mathrm{N}$ was fixed to 15 (value of BSG) for comparison the substrates. Different concentrations of urea were added to EGM, VTS, GS, COP ${ }^{\text {org }}$, COP, EOP and BSG to achieve at C/N ratio of 15 . Glass petri with solid medium were sterilized at $121^{\circ} \mathrm{C}$ for $15 \mathrm{~min}$. For inoculation, the fungi were suspended in a sterile solution $\left(1 \mathrm{~g} \mathrm{~L}^{-1}\right.$

Table 1

Composition of agro-industrial wastes. Values are expressed per dry mass of dry substrate.

\begin{tabular}{|c|c|c|c|c|c|c|c|}
\hline Parameter & $\mathrm{EGM}^{(1)}$ & $\mathrm{VST}^{(1)}$ & GS & $\mathrm{COP}^{\text {org }}$ & $\mathrm{COP}^{(2)}$ & $\mathrm{EOP}^{(2)}$ & BSG \\
\hline Humidity ( $\mathrm{g} \mathrm{kg}^{-1}$ ) & $109 \pm 1$ & $63.3 \pm 5.3$ & $570 \pm 12$ & $629 \pm 5$ & $735 \pm 4$ & $97 \pm 1$ & $64 \pm 2$ \\
\hline Total solids $\left(\mathrm{g} \mathrm{kg}^{-1}\right)$ & $891 \pm 1$ & $936.7 \pm 1$ & $430 \pm 15$ & $371 \pm 5$ & $265 \pm 4$ & $903 \pm 1$ & $936 \pm 2$ \\
\hline Ash $\left(\mathrm{g} \mathrm{kg}^{-1}\right)$ & $90.95 \pm 5.58$ & $35.87 \pm 4.32$ & $71 \pm 2$ & $37 \pm 8$ & $66 \pm 5$ & $34 \pm 2$ & $40.0 \pm 0.8$ \\
\hline Lignin $\left(\mathrm{g} \mathrm{kg}^{-1}\right)$ & $666.26 \pm 5.09$ & $340.85 \pm 5.54$ & $435 \pm 33$ & $431 \pm 11$ & $350 \pm 10$ & $550 \pm 20$ & $144 \pm 5$ \\
\hline Hemicellulose $\left(\mathrm{g} \mathrm{kg}^{-1}\right)$ & $101.78 \pm 3.81$ & $237.79 \pm 3.81$ & $133 \pm 35$ & $199 \pm 78$ & $390 \pm 50$ & $289.2 \pm 0.5$ & $243 \pm 35$ \\
\hline Cellulose $\left(\mathrm{g} \mathrm{kg}^{-1}\right)$ & $144.49 \pm 2.11$ & $423.96 \pm 5.25$ & $288 \pm 45$ & $188 \pm 37$ & $340 \pm 10$ & $129 \pm 2$ & $210 \pm 10$ \\
\hline $\mathrm{N}\left(\mathrm{g} \mathrm{kg}^{-1}\right)$ & $21.56 \pm 0.64$ & $6.06 \pm 0.03$ & $6.17 \pm 0.07$ & $6.1 \pm 0.3$ & $6 \pm 1$ & $9.2 \pm 0.6$ & $30.2 \pm 0.3$ \\
\hline Soluble Protein* $\left(\mathrm{g} \mathrm{kg}^{-1}\right)$ & $0.54 \pm 0.08$ & $0.54 \pm 0.08$ & $0.2 \pm 0.1$ & $0.14 \pm 0.03$ & $4 \pm 1$ & $0.54 \pm 0.08$ & $0.21 \pm 0.05$ \\
\hline Reducing sugars* $\left(\mathrm{g} \mathrm{kg}^{-1}\right)$ & $4.10 \pm 0.07$ & $4.10 \pm 0.07$ & $57 \pm 12$ & $29 \pm 2$ & $96 \pm 6$ & $33 \pm 2$ & $47.4 \pm 0.7$ \\
\hline Total Phenols* $\left(\mathrm{g} \mathrm{kg}^{-1}\right)$ & $1.72 \pm 0.01$ & $1.72 \pm 0.01$ & $4.44 \pm 0.08$ & $1.61 \pm 0.02$ & $8.4 \pm 0.3$ & $7.07 \pm 0.07$ & $0.55 \pm 0.05$ \\
\hline
\end{tabular}

VTS: vine trimming shoots; EGM: exhausted grape marc; EOP: Exhausted olive pomace; COP: crude olive pomace; COPorg: crude olive organic pomace; GS: grape stalk; BSG: brewer's spent grain. All values are expressed per kg of dry material; values are average \pm standard deviation.

*Value in aqueous extract.

(1) Sousa et al. (2018) (2) Leite et al. (2016). 
peptone and $0.1 \mathrm{~g} \mathrm{~L}^{-1}$ Tween 80 ). The inoculum spore concentration was adjusted to $10^{6}$ spores $\mathrm{mL}^{-1}$ using a Neubauer counting chamber. Each glass petri was inoculated with $2 \mathrm{~mL}$ of spore suspension and incubated at $25^{\circ} \mathrm{C}$ for 7 days. A control experience was performed for each sterilized waste without fungi and all SSF were performed in duplicate. At the end of each experiment, fermented and unfermented solid was used to extract enzymes and phenolic compounds with water, ratio liquid:solid of 5 , at room temperature with mechanical agitation for $30 \mathrm{~min}$. Following, extract was filtered through a nylon net and the liquid fraction was centrifuge at $4000 \mathrm{~g}$ for $10 \mathrm{~min}$ and $4{ }^{\circ} \mathrm{C}$. The enzyme extract was recovered and stored at $-20^{\circ} \mathrm{C}$ until its analysis.

\subsection{Analysis of total phenolic compounds}

Total phenols were measured by the Folin-Ciocalteu method (Commission Regulation (EEC) No. 2676/90). To each test tube was added $100 \mu \mathrm{L}$ of sample, or distilled water (to perform the blank), or caffeic acid solution (standard), $2 \mathrm{~mL}$ of $\mathrm{Na}_{2} \mathrm{CO}_{3}$ at $15 \%, 500 \mu \mathrm{L}$ of Folin-Ciocalteu reagent and $7.4 \mathrm{~mL}$ of distilled water. The test tubes were placed on a bath at $50{ }^{\circ} \mathrm{C}$ during $15 \mathrm{~min}$. After cooling at room temperature, the tubes were vortexed during $30 \mathrm{~s}$ proximally. After stabilization, the absorbance was read at $700 \mathrm{~nm}$. Calibration curve was constructed with standard solutions of caffeic acid with concentrations between $0 \mathrm{~g} \mathrm{~L}^{-1}$ and $2 \mathrm{~g} \mathrm{~L}^{-1}$. The units of TPC were defined as $\mathrm{mg}$ caffeic acid equivalents (CAE) $\mathrm{g}^{-1}$ dry solid (ds). Analysis were performed in duplicate.

\subsection{Analysis of enzymes activities}

The $\beta$-glucosidase was measured using the method described by Leite et al., 2016. $\beta$-glucosidase activity will be determined using pnitrophenyl- $\beta$-D-glucopyranoside (PNG) as substrate. The reaction was carried out adding $100 \mu \mathrm{L}$ of PNG to test tube and then $100 \mu \mathrm{L}$ of sample with suitable dilution in citrate buffer $0.05 \mathrm{~N} \mathrm{pH} 4.8$. The enzymatic reaction will be carried out at $50{ }^{\circ} \mathrm{C}$ for $15 \mathrm{~min}$. After $15 \mathrm{~min}$, it was added $600 \mu \mathrm{L}$ of $\mathrm{Na}_{2} \mathrm{CO}_{3}(1 \mathrm{M})$ and $1.7 \mathrm{~mL}$ of distilled water. Finally, the absorbance was read at $400 \mathrm{~nm}$ A calibration curve was made with 4nitrofenol with concentrations between $0 \mathrm{~g} \mathrm{~L}^{-1}$ and $100 \mathrm{~g} \mathrm{~L}^{-1}$. One International unit (IU) of enzyme activity was be defined as the quantity of enzyme required to liberate $1 \mu \mathrm{mol}$ of p-nitrophenol per minute under standard assay conditions. The values were expressed in units per gram of dry substrate $\left(\mathrm{U} \mathrm{g}^{-1}\right)$.

The procedure for determination of cellulases activity was to add $250 \mu \mathrm{L}$ of cellulase substrate (carboxymethylcellulose (CMC) $1 \%$ in $0.1 \mathrm{M}$ sodium acetate buffer, $\mathrm{pH} 4.6$ ) to test tubes and then, $250 \mu \mathrm{L}$ of diluted sample in buffer. The test tubes were placed on a bath at $50{ }^{\circ} \mathrm{C}$ for $30 \mathrm{~min}$. After $30 \mathrm{~min}$, it was added $500 \mu \mathrm{L}$ of DNS and then the test tubes were placed on a bath at $100{ }^{\circ} \mathrm{C}$ for $5 \mathrm{~min}$. Finally, they were added $5 \mathrm{~mL}$ of distilled water and the absorbance was read at $540 \mathrm{~nm}$. The blank was performed with sodium acetate buffer. A calibration curve was constructed with glucose standard solutions in buffer between $0 \mathrm{~g} \mathrm{~L}^{-1}$ and $2 \mathrm{~g} \mathrm{~L}^{-1}$. One unit of enzyme activity was defined as the amount of enzyme required to release $1 \mu \mathrm{mol}$ of glucose reducing sugar equivalents from $\mathrm{CMC}$ in $1 \mathrm{~min}$ at $50^{\circ} \mathrm{C}$ and $\mathrm{pH} 4.6$. The values of cellulases activity were expressed in units per gram of dry substrate (U $\left.\mathrm{g}^{-1}\right)$.

The procedure to determine the xylanases activity was the same as for the determination of cellulases activity but the duration of the reaction was of $15 \mathrm{~min}$ instead of $30 \mathrm{~min}$ and the substrate solution was xylan from beechwood (2\%). One unit of enzyme activity was defined as the amount of enzyme required to release $1 \mu \mathrm{mol}$ of xylose reducing sugar equivalents from beechwood xylan in $1 \mathrm{~min}$ at $50^{\circ} \mathrm{C}$ and $\mathrm{pH} 4.5$. The values of xylanases activity were expressed in units per gram of dry substrate $\left(\mathrm{U} \mathrm{g}^{-1}\right)$.

\subsection{Analysis of antioxidant capacity}

The antioxidant activity by DPPH scavenging method was described by Dulf et al., 2015 and using Trolox equivalent antioxidant capacity. An aqueous solution $(50 \mu \mathrm{L})$ of extract was placed in 96-well microplates, and $200 \mu \mathrm{L}$ of a $0.3 \mathrm{mmol} \mathrm{L}^{-1}$ methanolic solution of DPPH $(2,2$ diphenyl-1-picrylhydrazyl) was added and allowed to react in the dark at room temperature. After $30 \mathrm{~min}$, the decrease in absorbance of DPPH at $520 \mathrm{~nm}$ was measured. Methanol was used as blank solution, and a DPPH solution without test samples served as the control. All sample analyses were performed in duplicate. Known amounts of Trolox were used for calibration. The free radical scavenging activity of the extracts was expressed as micromoles of Trolox equivalents per gram dry solid substrate $\left(\mu \mathrm{mol} \mathrm{TE} \mathrm{g}^{-1}\right)$.

\subsection{Statistical analysis}

Principal components and data analyses were carried out with Statgraphics Plus 5.1 (Manusgistics, Inc., Rockville, MD).

\section{Results and discussion}

3.1. Phenolic compounds and antioxidant activity of agro-industrial wastes extracts

The extraction of TPC (total phenolic compounds) from agro-industrial wastes was evaluated using water, methanol or the mixture water:methanol $(1: 1, \mathrm{v} / \mathrm{v})$. The total phenols extracted from each waste are shown in Fig. 1. The TPC of agro-industrial wastes extracted with water ranged from $0.51 \pm 0.06$ to $4.44 \pm 0.11 \mathrm{~g} / \mathrm{kg}$ dry solid. Normally, the main phenolic compounds that are solubilized in water are in form of glycosides (Alberti et al., 2014). Grape stalk was the solid with higher TPC achieving $4.44 \mathrm{~g} / \mathrm{kg}$ dry solid, followed by the wastes from olive oil industry EOP, COP and $\mathrm{COP}^{\text {org }}$. On the contrary, the other wastes from wineries EGM and VTS and from breweries BSG showed a low TPC in water extracts. The grape marc was submitted to several treatments as alcoholic fermentation mixture with must, decanting and distillation that could remove the TPC that are soluble in water. However grape stalk is recovered at the start of winemaking processes, before pressing grapes thus this by-product was hardly treated and the TPC kept in the solid. Bustamante et al. (2008) also observed that GS was the waste from wineries with higher TPC. The extraction of phenolic compounds from BSG was low because the most of them are linked to polysaccharides and it is necessary a hydrolysis treatment to release them.

When only methanol was used as extraction solvent the higher TPCs were achieved from wastes of olive mills. The highest value was $6.13 \pm 0.06 \mathrm{mg} / \mathrm{g}$ COP. In the case of EGM, VTS, COP and COP ${ }^{\text {org }}$ the use of methanol increased the extraction of TPC compared to aqueous extraction. Methanol is considered a good solvent for low molecular weight polyphenols (Diem et al., 2014). Babbar et al. (2014) compared several solvents to evaluate the extraction of TPC and they observed that methanol was the best solvent due to the higher polarity and better solubility for phenolic compounds of vegetal biomass. To improve the extraction of phenolic compounds often the methanol is mixed with water (Diem et al., 2014). The increase of TPC using the mixture of methanol:water was significant only for VTS and COP ${ }^{\text {org }}$. This could be due to these wastes had low and high molecular weight polyphenols that their extraction was favoured by the mixture methanol:water. The wastes from olive mills had the maximum TPC, it was highlighted the high increase of TPC in VTS using methanol:water achieving 37.3\% compared to extraction with methanol. The mixture of these solvents allows to extract the phenolic compounds that are soluble in water and organic solvent (Diem et al., 2014). Based on the results, the mixture of methanol:water is the best extracting solvent for untreated agro-industrial wastes. In the next stage, this mixture and water were used as 


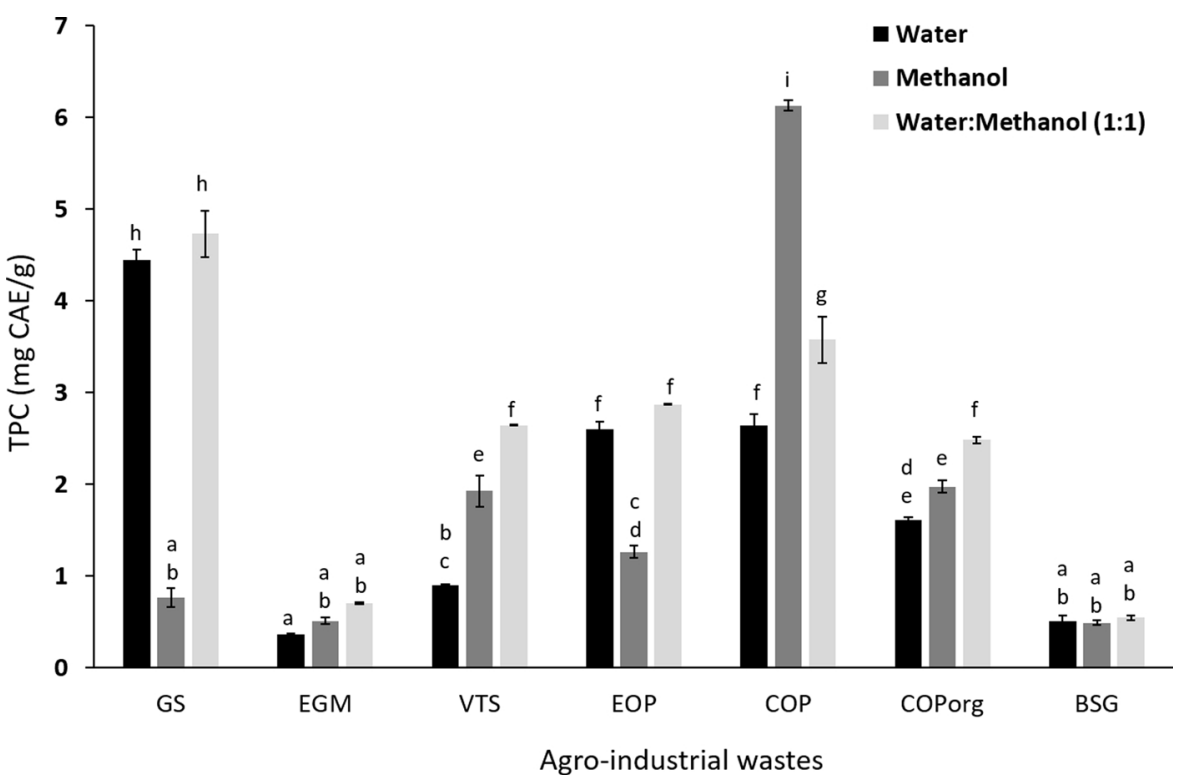

Fig. 1. Extraction of phenolic compounds from agroindustrial wastes. (GS: grape stalk; EGM: exhausted grape marc; VTS: vine trimming shoots; EOP: exhausted olive pomace; COP: crude olive pomace; $\mathrm{COP}^{\text {org: }}$ crude olive pomace from organic farming; BSG: brewer's spent grain). Values are average \pm standard deviation. Letters above each bar indicate the results of Tukey's test $(\mathrm{P}<0.05)$; values with shared letters in the same graph are not significantly different. extracting solvents for fermented agro-industrial waste to observe if the same effect occurs.

\subsection{Production of enzymes by solid-state fermentation}

The agro-industrial wastes were used as substrates in SSF by several fungi to observe the production of lignocellulolytic enzymes. Table 2 shows the xylanase activities achieved, the BSG was the best substrate for xylanase production by the five fungi studied. The low content of phenolic compounds and lignin and the high content of xylan could have favoured the production of xylanase. The production of xylanase and cellulase by fungi can be inhibited by phenolic compounds (Surendran et al., 2017) and the xylan can actuate as inductor (Curotto et al., 1994). In this waste, A. ibericus MUM 03.49 was the higher producer. Both $A$. ibericus showed higher activity than the other fungi tested. The use of BSG as substrate in SSF for lignocellulytic production are underexplored. However, they are highly susceptible to be used as substrate because it was not necessary to supplement with additional nutrient source unlike the winery and olive mill wastes that were supplemented by urea. In previous work, Sousa et al., 2018 observed that $A$. ibericus MUM 03.49 had higher endo-xylanase activity that other strains as A. uvarum and A. niger 01UAs181. In the present work, it was compared to another strains producers of xylanase and it was observed the same effect. Other authors used BSG to produce other ligninolytic enzymes by SSF as lignin and manganese peroxidases (Gassara et al., 2011). In SSF of winery wastes, the fermentation of EGM and VTS by $A$. ibericus and $A$. niger strains allowed to achieve the maxima xylanase activities compared to GS, this could be due to the high content of phenolic compounds in GS compared to EGM and VTS that inhibited the growth of fungi. The quantity of N of VTS and GS was lower
$0.61 \pm 0.01$ and $0.62 \pm 0.01 \%(\mathrm{w} / \mathrm{w})$, respectively. The $\mathrm{N}$ of EGM was higher $2.16 \pm 0.01 \%(\mathrm{w} / \mathrm{w})$, despite the fact that the ratio C:N was adjusted by adding urea to wastes with low nitrogen, the organic nitrogen of EGM could be more suitable for xylanase production. $\mathrm{N}$ source is considered an important factor for xylanase production (Lemos et al., 2001). In general, SSF of olive mill wastes improved the production of xylanases compared to winery wastes, however was lower than SSF of BSG. The strain $R$. oryzae only showed xylanase production using BSG as substrate. Only a strain of $R$. oryzae isolated from composed soil of Himalayan pine forest was identified as xylanase producer by SSF of shorgum stover (Pandey et al., 2016).

For cellulase production (Table 3), BSG was also the best substrate and the strain of $A$. ibericus MUM 04.86 achieved the maximum activity. However, A. ibericus MUM 03.49 and the $A$. niger strains showed similar activities. $R$. oryzae showed the lowest cellulase activity using BSG as substrate. Low cellulase production $(5.1 \mathrm{U} / \mathrm{g})$ was also observed by Kupski et al. (2014) in SSF of rice industry wastes. The winery waste that induced more the cellulase production was the VTS, in contrast to the effect observed in xylanase production. The fungus that achieved the maximum activity in VTS was A. ibericus MUM 03.49. The VTS had a higher content of cellulose $42.4 \pm 0.5 \%$ (w/w) than EGM $(14.4 \pm 0.5 \%(\mathrm{w} / \mathrm{w}))$ and GS $(29 \pm 5 \%(\mathrm{w} / \mathrm{w}))$, thus the higher cellulose content might have favoured the production of cellulase. A. ibericus MUM 03.49 was also the fungus that achieved the maximum cellulase activity in the SSF of olive mill wastes. Similar activities were achieved by this fungus using COP and EOP as substrate. However, the cellulase activity was lower when $\mathrm{COP}^{\text {org }}$ was fermented. The $\mathrm{COP}^{\text {org }}$ showed a low content in cellulose compared to COP, thus may affect the cellulase production. On the contrary, $R$. oryzae showed higher cellulase activity using $\mathrm{COP}^{\text {org }}$, the content of phenolic compounds of COP was

Table 2

Xylanase activities of extracts from SSF of agro-industrial wastes. Values are expressed as activity units per dry mass of substrate (U $g^{-1}$ ).

\begin{tabular}{|c|c|c|c|c|c|c|c|}
\hline Fungi & VTS & EGM & EOP & $\mathrm{COP}$ & $\mathrm{COP}^{\text {org }}$ & GS & BSG \\
\hline A.niger CECT2915 & $21.46 \pm 0.94^{\mathrm{bcd}}$ & $35.93 \pm 4.47^{\mathrm{def}}$ & $36.01 \pm 1.28^{\mathrm{ef}}$ & $20.70 \pm 0.31^{\text {bcde }}$ & $-{ }^{a}$ & $-^{a}$ & $290.55 \pm 0.01^{\mathrm{n}}$ \\
\hline A. niger CECT2088 & $20.09 \pm 0.26^{b c}$ & $70.45 \pm 1.16^{\mathrm{i}}$ & $26.00 \pm 0.88^{\text {bcde }}$ & $44.99 \pm 0.16^{\mathrm{fg}}$ & $91.81 \pm 9.79^{j}$ & $2.64 \pm 02.52^{\mathrm{a}}$ & $246.41 \pm 5.16^{\mathrm{m}}$ \\
\hline A. ibericus MUM 03.49 & $24.19 \pm 0.99^{\mathrm{bcde}}$ & $24.69 \pm 3.71^{\mathrm{bcde}}$ & $33.14 \pm 1.12^{\text {cdef }}$ & $53.91 \pm 3.52^{\mathrm{gh}}$ & $1.97 \pm 0.74^{\mathrm{a}}$ & $-{ }^{\mathrm{a}}$ & $313.83 \pm 5.25^{\mathrm{p}}$ \\
\hline A. ibericus MUM 04.86 & $13.24 \pm 0.79^{\mathrm{ab}}$ & $45.79 \pm 3.93^{\mathrm{fg}}$ & $127.05 \pm 4.3^{1}$ & $25.04 \pm 0.2^{\text {bcde }}$ & $61.14 \pm 3.71^{\mathrm{hi}}$ & $-{ }^{a}$ & $300.13 \pm 2.05^{\circ}$ \\
\hline R. oryzae MUM 10.260 & $-{ }^{\mathrm{a}}$ & $-{ }^{\mathrm{a}}$ & $-{ }^{a}$ & $-{ }^{\mathrm{a}}$ & $-{ }^{a}$ & $-{ }^{a}$ & $106.97 \pm 0.21^{\mathrm{k}}$ \\
\hline
\end{tabular}

VTS: vine trimming shoots; EGM: exhausted grape marc; EOP: Exhausted olive pomace; COP: crude olive pomace; COP $^{\text {org: }}$ crude olive organic pomace; GS: grape stalk; BSG: brewer's spent grain. Values are average \pm standard deviation. Letters indicate the results of Tukey's test $(\mathrm{P}<0.05)$; values with shared letters in the same graph are not significantly different. 
Table 3

Cellulase activities of extracts from SSF of agro-industrial wastes. Values are expressed as activity units per dry mass of substrate (U $g^{-1}$ ).

\begin{tabular}{|c|c|c|c|c|c|c|c|}
\hline Fungi & VTS & EGM & EOP & $\mathrm{COP}$ & $\mathrm{COP}^{\text {org }}$ & GS & BSG \\
\hline A.niger СЕСТ2915 & $11.7 \pm 0.08^{\text {abcdef }}$ & $7.86 \pm 0.14^{\mathrm{abc}}$ & $17.34 \pm 0.23^{\text {bcdefg }}$ & $15.27 \pm 1.31^{\text {bcdefg }}$ & $11.32 \pm 0.00^{\mathrm{abcdef}}$ & $5.34 \pm 5.94^{\mathrm{ab}}$ & $57.81 \pm 0.3^{\mathrm{h}}$ \\
\hline A. niger CECT2088 & $10.29 \pm 1.14^{\mathrm{abcde}}$ & $20.07 \pm 0.74^{\text {defg }}$ & $8.57 \pm 0.37^{\mathrm{abcd}}$ & $24.01 \pm 2^{g}$ & $22.33 \pm 2.4^{\mathrm{fg}}$ & $10.48 \pm 0.17^{\text {abcdef }}$ & $51.35 \pm 2.8^{\mathrm{h}}$ \\
\hline A. ibericus MUM 03.49 & $22.03 \pm 0.93^{\mathrm{efg}}$ & $7.34 \pm 0.61^{\mathrm{abc}}$ & $25.8 \pm 0.37^{g}$ & $26.43 \pm 1.15^{\mathrm{g}}$ & $11.83 \pm 5.11^{\mathrm{abcdef}}$ & $2.67 \pm 0.44^{\mathrm{a}}$ & $51.31 \pm 0.00^{\mathrm{h}}$ \\
\hline A. ibericus MUM 04.86 & $18.28 \pm 1.61^{\mathrm{cdefg}}$ & $9.4 \pm 0.11^{\mathrm{abcd}}$ & $24.46 \pm 2.13^{g}$ & $16.64 \pm 1.54^{\text {bcdefg }}$ & $20.16 \pm 0.49^{\text {defg }}$ & $1.24 \pm 0.6^{\mathrm{a}}$ & $62.37 \pm 5.48^{\mathrm{h}}$ \\
\hline R. oryzae MUM 10.260 & $-{ }^{\mathrm{a}}$ & $-{ }^{\mathrm{a}}$ & $2.4 \pm 0.55^{\mathrm{a}}$ & $a^{\mathrm{a}}$ & $-^{\mathrm{a}}$ & $0.73 \pm 0.69^{\mathrm{a}}$ & $18.13 \pm 6.76^{\text {cdefg }}$ \\
\hline
\end{tabular}

VTS: vine trimming shoots; EGM: exhausted grape marc; EOP: Exhausted olive pomace; COP: crude olive pomace; COP ${ }^{\text {org: }}$ crude olive organic pomace; GS: grape stalk; BSG: brewer's spent grain. Values are average \pm standard deviation.

Table 4

$\beta$-glucosidase activities of extracts from SSF of agro-industrial wastes. Values are expressed as activity units per dry mass of substrate (U $g^{-1}$ ).

\begin{tabular}{|c|c|c|c|c|c|c|c|}
\hline Fungi & VTS & EGM & EOP & COP & $\mathrm{COP}^{\text {org }}$ & GS & BSG \\
\hline A.niger CECT2915 & $2.87 \pm 0.09^{\mathrm{abc}}$ & $3.3 \pm 0.15^{\mathrm{abcd}}$ & $3.05 \pm 0.21^{\mathrm{abc}}$ & - & $0.23 \pm 0.03^{\mathrm{ab}}$ & $0.02 \pm 0.02^{\mathrm{a}}$ & $3.89 \pm 0.2^{\text {bcde }}$ \\
\hline A. niger СЕСТ2088 & $19.18 \pm 1.26^{\mathrm{h}}$ & $2.46 \pm 0.28^{\mathrm{abc}}$ & $28.31 \pm 0.03^{\mathrm{i}}$ & $2.23 \pm 0.04^{\mathrm{abc}}$ & $14.12 \pm 0.22^{g}$ & $0.25 \pm 0.04^{\mathrm{ab}}$ & $93.66 \pm 3.77^{j}$ \\
\hline A. ibericus MUM 03.49 & $7.15 \pm 0.48^{\mathrm{ef}}$ & $2.11 \pm 0.08^{\mathrm{abc}}$ & $22.17 \pm 0.18^{\mathrm{h}}$ & $3.12 \pm 0.09^{\mathrm{abcd}}$ & $0.18 \pm 0.01^{\mathrm{ab}}$ & $\mathrm{a}^{\mathrm{a}}$ & $4.06 \pm 0.18^{\text {cde }}$ \\
\hline A. ibericus MUM 04.86 & $6.91 \pm 0.12^{\mathrm{def}}$ & $4.71 \pm 0.01^{\text {cde }}$ & $3.17 \pm 0.24^{\mathrm{abcd}}$ & - & $7.6 \pm 0.36^{\mathrm{ef}}$ & $\mathrm{a}^{\mathrm{a}}$ & $9.77 \pm 0.65^{\mathrm{f}}$ \\
\hline R. oryzae MUM 10.260 & $\mathrm{a}^{\mathrm{a}}$ & $\stackrel{\mathrm{a}}{ }^{\mathrm{a}}$ & $\mathrm{a}^{\mathrm{a}}$ & $-^{\mathrm{a}}$ & $\mathrm{a}^{\mathrm{a}}$ & $\mathrm{a}^{\mathrm{a}}$ & $1.12 \pm 0.37^{\mathrm{abc}}$ \\
\hline
\end{tabular}

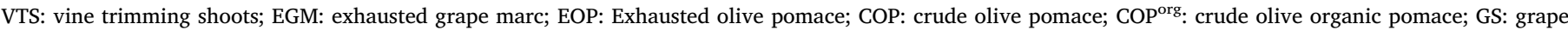

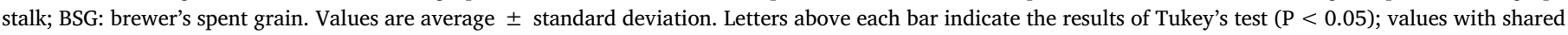
letters in the same graph are not significantly different.

higher than $\mathrm{COP}^{\text {org }}, R$. oryzae might be affected by them and to limit the production of enzymes.

In the case of $\beta$-glucosidase production (Table 4), A. niger CECT 2088 was the fungus that showed the maximum $\beta$-glucosidase activity after SSF of BSG, VTS, EOP and COP ${ }^{\text {org }}$. It was highlighted the high activity $93.66 \pm 3.77 \mathrm{U} / \mathrm{g}$ using BSG as substrate. Using other substrates often explored in SSF as wheat bran, it was achieved $71.3 \mathrm{U} / \mathrm{g}$ of $\beta$-glucosidase activity by $A$. niger strain (Kumar et al., 2018). Marques et al. (2018) studied 4 fungi that stood out in $\beta$-glucosidase production (Saccharicola sp., Paecilomyces sp., Ustilaginoidea sp. and Ustilaginoidea sp.), and the $\beta$-glucosidase activities ranged from 21.7 to $51.6 \mathrm{U} / \mathrm{g}$ using a mixture of sugarcane bagasse and wheat bran as substrate. $A$. ibericus MUM 03.49 also showed a good production using EOP as substrate, the production of $\beta$-glucosidase using winery wastes was lower, excepting A. niger CECT 2088 using VTS that achieved a high value $19.18 \pm 3.77 \mathrm{U} / \mathrm{g}$.

\subsection{Effect of solid-state fermentation on phenolic compounds}

The TPC from fermented agro-industrial wastes was analysed after water extraction and compared with unfermented wastes (controls)
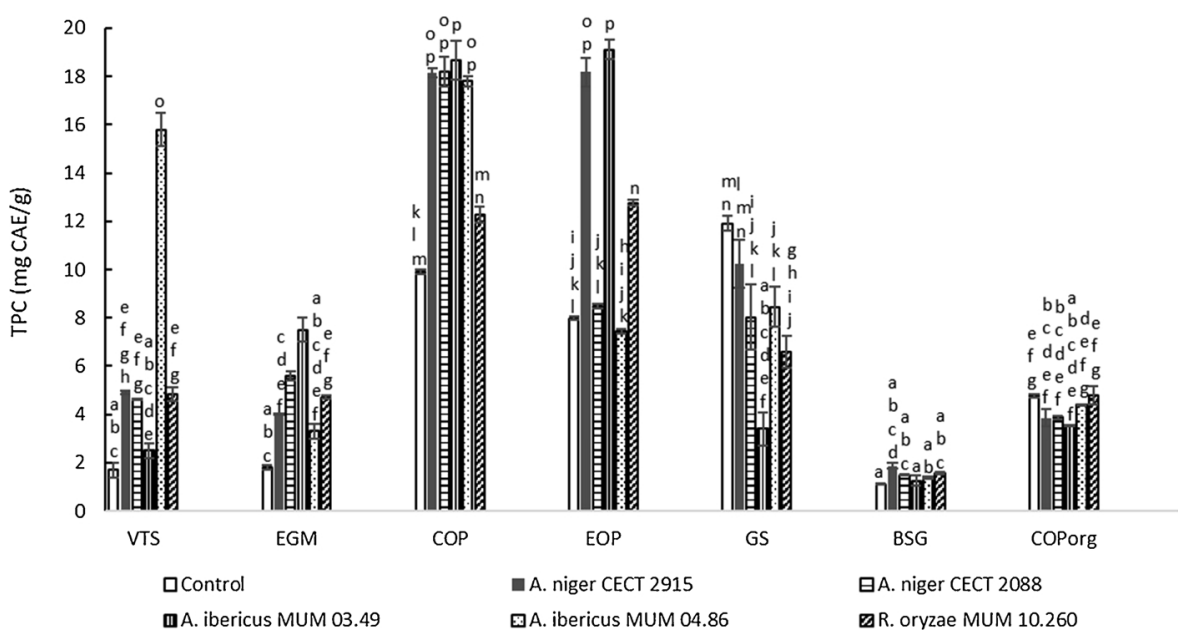

(Fig. 2). The release of TPC was increased in VTS, EGM, COP, EOP and BSG respect to unfermented wastes. However, SSF of GS and $\mathrm{COP}^{\text {org }}$ reduced the content of phenolic compounds. This effect may be due to the formation of polymeric forms of phenolic compounds activated in response to low content in $\mathrm{N}$ and $\mathrm{C}$ (Dulf et al., 2018). The maximum increase of TPC was observed in fermented VTS by A. ibericus MUM 04.86 (2.9-fold) respect to unfermented VTS. The strain A. ibericus MUM 03.49 was the fungus that achieved the maximum release of TPC after SSF of EGM, COP and EOP. Several authors have observed the increase of phenolic content after SSF by Aspergillus sp., however the increase of TPC using A. ibericus has yet to be observed. Dulf et al. (2018) studied the liberation of phenolic compounds of chokeberry by SSF with A. niger and it was increased the extraction of TPC 1.7 -fold. In addition, it was studied the extraction of TPC of plum fruit by SSF with A.niger increasing the phenolic content by over 21\% (Dulf et al., 2016). The extraction of TPC was not increased in EOP using A. ibericus MUM 04.86 and similar value was observed in A. niger CECT 2088. These wastes have phenolic compounds conjugated to glycosides as oleuropein (Cioffi et al., 2010). The hydrolytic enzymes produced by fungus can hydrolyse these compounds to free phenolics as hydroxytyrosol (Liu et al., 2018).
Fig. 2. Total phenolic content extracted from fermented and unfermented (control) agro-industrial wastes. (GS: grape stalk; EGM: exhausted grape marc; VTS: vine trimming shoots; EOP: exhausted olive pomace; COP: crude olive pomace; COP $^{\text {org. }}$ crude olive pomace from organic farming; BSG: brewer's spent grain; TPC: total phenolic compounds; CAE: caffeic acid equivalents). Values are average \pm standard deviation. Letters above each bar indicate the results of Tukey's test $(\mathrm{P}<0.05)$; values with shared letters in the same graph are not significantly different. 


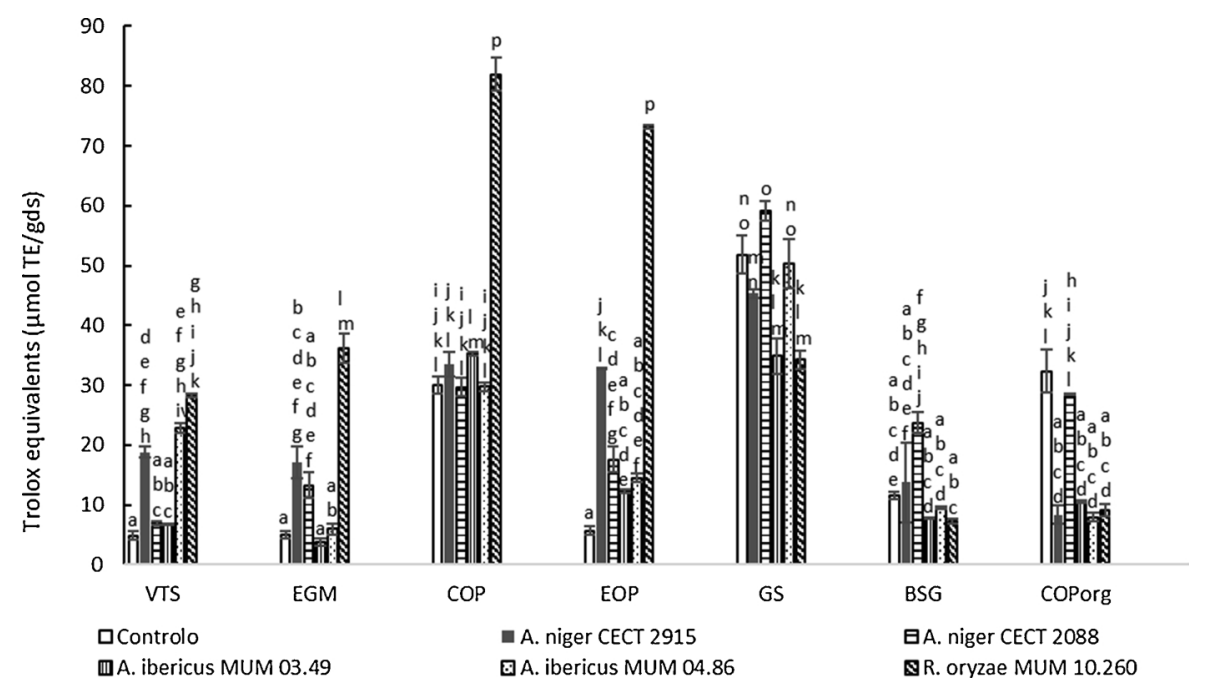

Fig. 3. Antioxidant activity of water extracts from fermented and unfermented (control) agro-industrial wastes. (GS: grape stalk; EGM: exhausted grape marc; VTS: vine trimming shoots; EOP: exhausted olive pomace; COP: crude olive pomace; $\mathrm{COP}^{\text {org: }}$ crude olive pomace from organic farming; BSG: brewer's spent grain; TPC: total phenolic compounds; TE: Trolox equivalents). Values are average \pm standard deviation. Letters above each bar indicate the results of Tukey's test $(\mathrm{P}<0.05)$; values with shared letters in the same graph are not significantly different.
The extraction of phenolic compounds from BSG was lower, A. niger CECT 2915 achieved the maximum extraction of TPC $1.86 \pm 0.11 \mathrm{mg}$ $\mathrm{CAE} / \mathrm{gds}$. However, the extraction was the same order to other extraction techniques as ultrasounds and microwaves 4.11 and $3.91 \mathrm{mg}$ gallic acid equivalent/gds in ethanol:water extracts, respectively (Carciochi et al., 2018). The phenolic compounds of BSG are linked to hemicellulose and lignin fraction, however the action of enzymes produced during SSF not allowed their extraction. This may be because the temperature of fermentation $\left(25^{\circ} \mathrm{C}\right)$ was not the optimal temperature for the action of lignocellulosic enzymes. Thus, to increase the extraction of TPC a enzymatic hydrolysis may be performed (Crowley et al., 2017).

\subsection{Effect of solid-state fermentation on antioxidant activity}

The antioxidant activity of fermented and unfermented agro-industrial wastes in water extracts was evaluated. The inhibition of DPPH free radical by the action of phenolic compounds extracted by water from fermented and unfermented agro-industrial wastes is showed in Fig.3. The maximum increase of antioxidant activity respect to control was observed in olive mill wastes (12.9-fold for EOP and 2.7-fold for $\mathrm{COP}$ ) and winery wastes (7.2-fold for EGM and 5.8-fold for VTS) fermented by $R$. oryzae. The effect of this fungus on antioxidant activity has already tested in SSF of rice bran, however the antioxidant activity was not increased with fermentation (Schmidt et al., 2014). On the other hand, the SSF of soybean okara by R. oryzae increased the DPPH activity 1.7-fold (Queiroz et al., 2018). The antioxidant activity of EGM was improved by all microorganisms except to A. ibericus MUM 03.49. Martins et al. (2016) evaluated the increase of DPPH antioxidant activity of grape marc by enzymatic treatment and it was improved 1.8fold after treatment.

In the case of BSG and GS the maximum increase of antioxidant activity was achieved by $A$. niger CECT 2088 (2-fold). The antioxidant activity of extracts from BSG is normally correlated with the concentration of hydroxycinnamic acids as caffeic acid (Mccarthy et al., 2013). These hydroxycinnamic acids are linked to hemicellulose and lignin fraction, thus the action of fungal enzymes allowed release the free phenolics and increase the antioxidant activity.

\subsection{Principal component analysis}

The production of enzymes, extraction of phenolic compounds and the antioxidant activity were studied in a principal component analysis (PCA). This tool allows to reduce the variable studied in two principal components, which describes the relation between variables. The two principal components are shown in Fig. 4 and explaining $49.97 \%$ and $24.1 \%$ of total variance, respectively. The first component was characterized by major production of enzymes in the positive side and TPC and DPPH activity in the negative side. The TPC and antioxidant activity were correlated, this is related to the antioxidant properties of

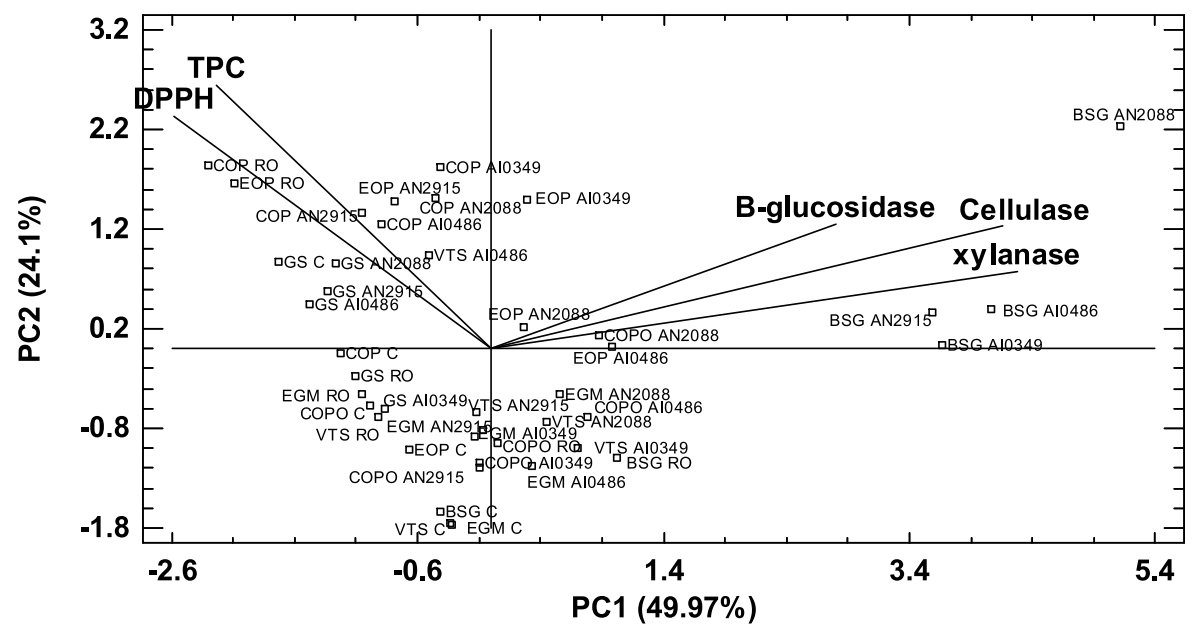


wastes. 
phenolic compounds (Nascimento et al., 2018). For the second component, all variables showed a positive effect, thus the high enzymes activities were positively correlated to the extraction of phenolic compounds and the high antioxidant activity. In addition, the PC1 grouped the BSG fermented in the region of the high production of cellulase, xylanase and $\beta$-glucosidase on the right side. In addition, it grouped the wastes fermented by $R$. oryzae in the left side due to the low production of enzymes and the high increase of antioxidant activity and the high extraction of phenolic compounds. On the other hand, the PC2 grouped the results of SSF of COP and EOP that had a high extraction of phenolic compounds and an increase of antioxidant activity. Moreover PC2 grouped the winery wastes and $\mathrm{COP}^{\text {org }}$ in the negative side due to the low antioxidant activity and extraction of phenolic compounds.

\section{Conclusions}

The SSF was an effective process to increase the extraction of antioxidant phenolic compounds from winery, olive mill and brewery wastes and simultaneously the production of lignocellulolytic enzymes. The study allowed to identify the fungi and the agro-industrial wastes that produced high cellulase, xylanase and $\beta$-glucosidase and that increased the extraction of phenolic compounds. BSG was the waste most appropriate for lignocellulolytic enzymes production by SSF and the strains of $A$. ibericus were the best enzyme producers. On the other hand, the extraction of TPC and the increase of antioxidant activity by SSF was higher in olive mill and winery wastes. Overall, the biological treatment by SSF allowed to increase the extraction of antioxidant compounds from agro-industrial wastes, which is an environmentally friendly process that not use organic solvents.

\section{Acknowledgements}

Paulina Leite is recipient of a fellowship supported by the Portuguese Foundation for Science and Technology (FCT) under the scope of the strategic funding of SFRH/BD/114777/2016.

José Manuel Salgado was supported by grant CEB/N2020 - INV/01/ 2016 from Project "BIOTECNORTE - Underpinning Biotechnology to foster the north of Portugal bioeconomy" (NORTE-01-0145-FEDER000004). This study was supported by the Portuguese Foundation for Science and Technology (FCT) under the scope of the strategic funding of UID/BIO/04469/2013 unit and COMPETE 2020 (POCI-01-0145FEDER-006684) and BioTec-Norte operation (NORTE-01-0145-FEDER000004) funded by the European Regional Development Fund under the scope of Norte2020 - Programa Operacional Regional do Norte.

\section{References}

Alberti, A., Antonio, A., Zielinski, F., Marinho, D., Mottin, I., Nogueira, A., Igarashi, L., 2014. Optimisation of the extraction of phenolic compounds from apples using response surface methodology. Food Chem. 149, 151-158. https://doi.org/10.1016/j. foodchem.2013.10.086.

Babbar, N., Oberoi, H.S., Sandhu, S.K., Bhargav, V.K., 2014. Influence of different solvents in extraction of phenolic compounds from vegetable residues and their evaluation as natural sources of antioxidants. J. Food Sci. Technol. 51, 2568-2575. https://doi.org/10.1007/s13197-012-0754-4.

Bartolomé, B., Faulds, C.B., Williamson, G., 1997. Enzymic release of ferulic acid from barley spent grain. J. Cereal Sci. 25, 285-288. https://doi.org/10.1006/jcrs.1996. 0091.

Bartolomé, B., Santos, M., Jiménez, J.J., Nozal, M.J., Gómez-Cordovés, C., 2002. Pentoses and hydroxycinnamic acids in Brewer's spent grain. J. Cereal Sci. 36, 51-58. https:// doi.org/10.1006/jcrs.2002.0442.

Bartolomé, B., Gómez-Cordovés, C., Sancho, A.I., Díez, N., Ferreira, P., Soliveri, J., CopaPatiño, J.L., 2003. Growth and release of hydroxycinnamic acids from Brewer's spent grain by Streptomyces avermitilis CECT 3339. Enzyme Microb. Technol. 32 , 140-144. https://doi.org/10.1016/S0141-0229(02)00277-6.

Bei, Q., Chen, G., Lu, F., Wu, S., Wu, Z., 2018. Enzymatic action mechanism of phenolic mobilization in oats (Avena sativa L.) during solid-state fermentation with Monascus anka. Food Chem. 245, 297-304. https://doi.org/10.1016/j.foodchem.2017.10.086.

Bendini, A., Cerretani, L., Carrasco-Pancorbo, A., Gómez-Caravaca, A.M., SeguraCarretero, A., Fernández-Gutiérrez, A., Lercker, G., 2007. Phenolic molecules in virgin olive oils: a survey of their sensory properties, health effects, antioxidant activity and analytical methods. An overview of the last decade. Molecules 12, 1679-1719. https://doi.org/10.3390/12081679.

Bhanja, T., Kumari, A., Banerjee, R., 2009. Enrichment of phenolics and free radical scavenging property of wheat koji prepared with two filamentous fungi. Bioresour. Technol. 100, 2861-2866.

Bustamante, M.A., Moral, R., Paredes, C., Pérez-Espinosa, A., Moreno-Caselles, J., PérezMurcia, M.D., 2008. Agrochemical characterisation of the solid by-products and residues from the winery and distillery industry. Waste Manag. 28, 372-380. https:// doi.org/10.1016/j.wasman.2007.01.013.

Carciochi, R.A., Sologubik, C.A., Fern, B., Manrique, G.D., Galv, L., Id, D.A., 2018. Extraction of antioxidant phenolic compounds from Brewer's spent grain: optimization and kinetics modeling. Antioxidants 7, 45. https://doi.org/10.3390/ antiox7040045.

Cioffi, G., Pesca, M.S., De Caprariis, P., Braca, A., Severino, L., De Tommasi, N., 2010. Phenolic compounds in olive oil and olive pomace from Cilento (Campania, Italy) and their antioxidant activity. Food Chem. 121, 105-111. https://doi.org/10.1016/j. foodchem.2009.12.013.

Crowley, D., O'Callaghan, Y., Mccarthy, A.L., Connolly, A., Fitzgerald, R.J., O’Brien, N.M., 2017. Aqueous and enzyme-extracted phenolic compounds from brewers' spent grain (BSG): assessment of their antioxidant potential. J. Food Biochem. 41, e12370. https://doi.org/10.1111/jfbc.12370.

Curotto, E., Concha, M., Campos, V., Milagres, A.M.F., Duran, N., 1994. Production of extracellular xylanases by Penicillium janthinellum. Appl. Biochem. Biotechnol. 48, 107-116. https://doi.org/10.1007/BF02796165.

Dey, T.B., Kuhad, R.C., 2014. Enhanced production and extraction of phenolic compounds from wheat by solid-state fermentation with Rhizopus oryzae RCK2012. Biotechnol. Rep. 4, 120-127.

Diem, Q., Elisa, A., Tran-nguyen, P.L., 2014. ScienceDirect Effect of extraction solvent on total phenol content, total flavonoid content, and antioxidant activity of Limnophila aromatica. J. Food Drug Anal. 22, 296-302. https://doi.org/10.1016/j.jfda.2013.11. 001.

Dulf, F.V., Vodnar, D.C., Dulf, E.H., Toşa, M.I., 2015. Total phenolic contents, antioxidant activities, and lipid fractions from berry pomaces obtained by solid-state fermentation of two Sambucus species with Aspergillus niger. J. Agric. Food Chem. 63, 3489-3500. https://doi.org/10.1021/acs.jafc.5b00520.

Dulf, F.V., Vodnar, D.C., Socaciu, C., 2016. Effects of solid-state fermentation with two filamentous fungi on the total phenolic contents, flavonoids, antioxidant activities and lipid fractions of plum fruit (Prunus domestica L.) by-products. Food Chem. 209, 27-36. https://doi.org/10.1016/j.foodchem.2016.04.016.

Dulf, F.V., Vodnar, D.C., Dulf, E.-H., Diaconeasa, Z., Socaciu, C., 2018. Liberation and recovery of phenolic antioxidants and lipids in chokeberry (Aronia melanocarpa) pomace by solid-state bioprocessing using Aspergillus niger and Rhizopus oligosporus strains. LWT - Food Sci. Technol. 87, 241-249. https://doi.org/10.1016/j.lwt.2017. 08.084.

Faulds, C., Sancho, A.I., Bartolomé, B., 2002. Mono- and dimeric ferulic acid release from brewer's spent grain by fungal feruloyl esterases. Appl. Microbiol. Biotechnol. 60, 489-493. https://doi.org/10.1007/s00253-002-1140-3.

Gassara, F., Brar, S.K., Tyagi, R.D., John, R.P., Verma, M., Valero, J.R., 2011. Parameter optimization for production of ligninolytic enzymes using agro-industrial wastes by response surface method. Biotechnol. Bioprocess Eng. 16, 343-351. https://doi.org/ 10.1007/s12257-010-0264-z.

Kumar, B.A., Amit, K., Alok, K., Dharm, D., 2018. Wheat bran fermentation for the production of cellulase and xylanase by Aspergillus niger NFCCI 4113. Res. J. Biotechnol. 13.

Kupski, L., Pagnussatt, F.A., Buffon, J.G., Furlong, E.B., 2014. Endoglucanase and total cellulase from Newly Isolated Rhizopus oryzae and Trichoderma reesei: production, characterization, and thermal stability. Appl. Biochem. Biotechnol. 172, 458-468. https://doi.org/10.1007/s12010-013-0518-2.

Lafka, T.-I., Lazou, A.E., Sinanoglou, V.J., Lazos, E.S., 2011. Phenolic and antioxidant potential of olive oil mill wastes. Food Chem. 125, 92-98.

Leite, P., Salgado, J.M., Venâncio, A., Domínguez, J.M., Belo, I., 2016. Ultrasounds pretreatment of olive pomace to improve xylanase and cellulase production by solidstate fermentation. Bioresour. Technol. 214, 737-746. https://doi.org/10.1016/j. biortech.2016.05.028.

Lemos, J.L.S., De, A., Fontes, M.C., Pereira Jr., N., 2001. Xylanase production by Aspergillus awamori in solid-state fermentation and influence of different nitrogen sources. Appl. Biochem. Biotechnol. 91-93, 681-690. https://doi.org/10.1385/ ABAB:91-93:1-9:681.

Liu, M., Yong, Q., Yu, S., 2018. Efficient bioconversion of oleuropein from olive leaf extract to antioxidant hydroxytyrosol by enzymatic hydrolysis and high-temperature degradation. Biotechnol. Appl. Biochem. 65, 1-10. https://doi.org/10.1002/bab. 1651.

Marques, N., Pereira, J.D.C., Gomes, E., Regina, A., Ferreira, H., Rodrigues, A., Johana, K., Alonso, D., 2018. Industrial Crops \& Products Cellulases and xylanases production by endophytic fungi by solid state fermentation using lignocellulosic substrates and enzymatic sacchari fi cation of pretreated sugarcane bagasse. Ind. Crop. Prod. 122, 66-75. https://doi.org/10.1016/j.indcrop.2018.05.022.

Martins, I.M., Roberto, B.S., Blumberg, J.B., Chen, C.Y.O., Macedo, G.A., 2016. Enzymatic biotransformation of polyphenolics increases antioxidant activity of red and white grape pomace. Food Res. Int. 89, 533-539. https://doi.org/10.1016/j.foodres.2016. 09.009.

Mccarthy, A.L., Callaghan, Y.C.O., Neugart, S., Piggott, C.O., Connolly, A., Jansen, M.A.K., Krumbein, A., Schreiner, M., Fitzgerald, R.J., Brien, N.M.O., 2013. The hydroxycinnamic acid content of barley and brewers' spent grain (BSG) and the potential to incorporate phenolic extracts of BSG as antioxidants into fruit beverages. 
Food Chem. 141, 2567-2574. https://doi.org/10.1016/j.foodchem.2013.05.048.

Meneses, N.G.T., Martins, S., Teixeira, J.A., Mussatto, S.I., 2013. Influence of extraction solvents on the recovery of antioxidant phenolic compounds from brewer's spent grains. Sep. Purif. Technol. 108, 152-158. https://doi.org/10.1016/j.seppur.2013. 02.015 .

Mussatto, S.I., Dragone, G., Roberto, I.C., 2007. Ferulic and p-coumaric acids extraction by alkaline hydrolysis of brewer's spent grain. Ind. Crops Prod. 25, 231-237. https:// doi.org/10.1016/j.indcrop.2006.11.001.

Nascimento, K.S., do Gasparotto Sattler, J.A., Lauer Macedo, L.F., Serna González, C.V., Pereira de Melo, I.L., da Silva Araújo, E., Granato, D., Sattler, A., de AlmeidaMuradian, L.B., 2018. Phenolic compounds, antioxidant capacity and physicochemical properties of Brazilian Apis mellifera honeys. LWT 91, 85-94. https://doi.org/10. 1016/j.lwt.2018.01.016.

Obied, H.K., Allen, M.A., Bedgood, D.R., 2005. Bioactivity and analysis of biophenols recovered from olive mill waste. J. Agric. Food Chem. 53, 823-837. https://doi.org/ 10.1021/jf048569x.

Pandey, A., 2003. Solid-state fermentation. Biochem. Eng. J. 13, 81-84. https://doi.org/ 10.1016/S1369-703X(02)00121-3.

Pandey, A., Edgard, G., Negi, S., 2016. Optimization of concomitant production of cellulase and xylanase from Rhizopus oryzae SN5 through EVOP-factorial design technique and application in Sorghum stover based bioethanol production. Renew. Energy 98, 51-56. https://doi.org/10.1016/j.renene.2016.05.071.

Queiroz, V.A., Nascimento, C.G., Schmidt, C.A.P., Mantovani, D., Dekker, R.F.H. Antônio, M., Cunha, A., 2018. Solid-state fermentation of soybean okara: iso fl avones biotransformation, antioxidant activity and enhancement of nutritional quality. LWT - Food Sci. Technol. 92, 509-515. https://doi.org/10.1016/j.lwt.2018.02.067.

Rodríguez-Solana, R., Salgado, J.M., Domínguez, J.M., Cortés-Diéguez, S., 2014.

Characterization of fennel extracts and quantification of estragole: Optimization and comparison of accelerated solvent extraction and Soxhlet techniques. Ind. Crop. Prod. 52, 528-536. https://doi.org/10.1016/j.indcrop.2013.11.028.

Schmidt, C.G., Gonçalves, L.M., Prietto, L., Hackbart, H.S., Furlong, E.B., 2014 Antioxidant activity and enzyme inhibition of phenolic acids from fermented rice bran with fungus Rizhopus oryzae. Food Chem. 146, 371-377. https://doi.org/10. 1016/j.foodchem.2013.09.101.

Singhania, R.R., Patel, A.K., Soccol, C.R., Pandey, A., 2009. Recent advances in solid-state fermentation. Biochem. Eng. J. 44, 13-18. https://doi.org/10.1016/j.bej.2008.10. 019.

Sousa, D., Venâncio, A., Belo, I., Salgado, J.M., 2018. Mediterranean agro-industrial wastes as valuable substrates for lignocellulolytic enzymes and protein production by solid-state fermentation. J. Sci. Food Agric. 98, 5248-5256.

Surendran, A., Siddiqui, Y., Mohd Saud, H., SA, N., Manickam, S., 2017. The antagonistic effect of phenolic compounds on ligninolytic and cellulolytic enzymes of Ganoderma Boninense, causing basal stem rot in Oil Palm. Int. J. Agric. Biol. https://doi.org/10. 17957/IJAB/15.0439.

Tournour, H.H., Segundo, M.A., Magalhães, L.M., Barreiros, L., Queiroz, J., Cunha, L.M., 2015. Valorization of grape pomace: extraction of bioactive phenolics with antioxidant properties. Ind. Crop. Prod. 74, 397-406. https://doi.org/10.1016/j.indcrop. 2015.05.055. 